\title{
Quality analysis of galvanized pipes applied to natural gas installations in civil construction
}

\author{
Fernando Benedicto Mainier ${ }^{1}$, Rodolfo Gomes Shamá dos Santos ${ }^{1}$, \\ Humberto Nogueira Farneze ${ }^{2}$
}

\footnotetext{
${ }^{1}$ Escola de Engenharia, Universidade Federal Fluminense, Niterói, Rio de Janeiro, Brasil.

${ }^{2}$ Centro Federal de Educação Tecnológica Celso Suckow da Fonseca de Itaguaí, Itaguaí, Rio de Janeiro, Brasil. e-mail: fmainier@uol.com.br, roshama@ hotmail.com, humbertofanzese@gmail.com
}

\begin{abstract}
Some natural gas distributors for residential and commercial buildings in Brazil use galvanized steel tubes and fittings manufactured by the hot-dip zinc process that are supported by the specifications contained in the Brazilian Standards. Zinc coating is one of the most widely used methods to provide protection against corrosion. It is therefore essential that national and international tube manufacturers and installation and maintenance companies in civil construction also meet the defined national and international standards, especially when the tubes and fittings are used for natural gas in residential buildings. This two-way communication could eliminate most issues that delay or prevent superior galvanizing quality. Low standards lead to the deterioration of the zinc coating and the metal base of the pipes, which may lead to leaks, such as fluids, flammable gases, and other toxic products, and potentially jeopardise residential and commercial buildings. Here the importance of ensuring the quality of zinc-coated pipes is demonstrated through a series of analyses on natural gas pipe corrosion used in civil construction in Brazil. Based on Brazilian standards, the zinc mass determination per square meter, uniformity tests (Preece test) and metallographic evaluation of the deposited zinc layer were carried out on samples of galvanized tubes for natural gas. An experiment was also developed to reproduce the same conditions of subfloors (mortar beds) where there is penetration of water and humidity reaching the galvanized pipes. Metallographic analysis showed that samples of galvanized tubes by the hot-dip zinc galvanizing can have discontinuities and defects in zinc layer. Such defects associated with penetration and/or permeation of the water and humidity in the subfloor favor the corrosive process and consequently can cause gas leaks and probable accidents in residential buildings.
\end{abstract}

Keywords: Corrosion, galvanized steel, zinc coating, quality, natural gas pipes, civil construction.

\section{INTRODUCTION}

The natural gas distribution companies in some Brazilian cities currently use galvanized pipes manufactured by the hot-dip zinc process for residential and commercial buildings that are supported by Brazilian Standards ABNT [1-3]. However, there has recently been a notable increase in external corrosion processes, especially in the subfloor (mortar beds), as shown in Figure 1.

Some corrosion was so serious that major renovations and the installation of new pipes by several construction companies was required, even before the five-year warranty expired, resulting in damage, inconvenience to tenants and residents, and especially the enormous risk of gas leaks, fires and consequent explosions. 

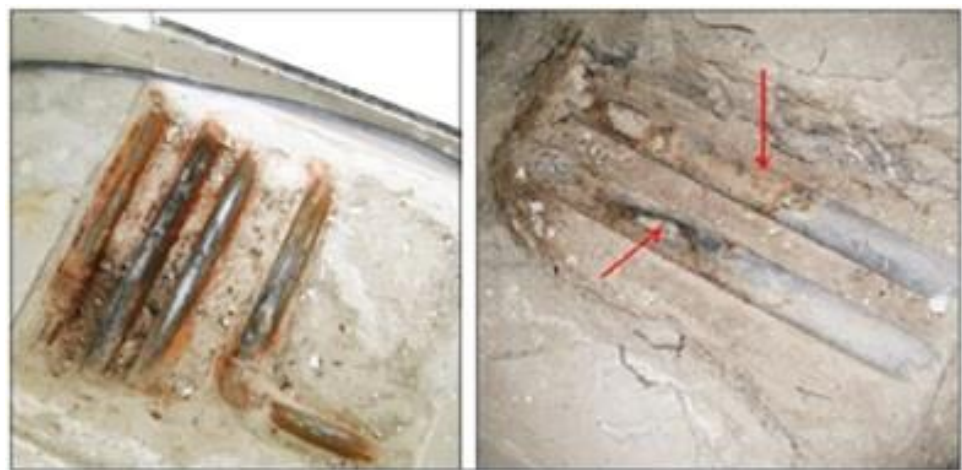

Figure 1: Aspects of external corrosion on galvanized steel pipes.

Mainier [4] attributed many of these issues to the premature corrosion of galvanized steel pipes, which are due to the poor quality of their coatings and/or the chemical additives used for mortars. Once placed to the subfloors (mortar beds), these can result in corrosion of the zinc coating, which leads to localised corrosion points (holes) in the carbon steel and eventual gas leaks.

The objective here is to highlight the critical importance of high-quality hot-dip zinc galvanized coatings in natural gas pipelines that are used in civil construction. The analysis is based on knowledge of the manufacturing process of the galvanized elements, the inspections and tests, as well as the technical specifications governing the final product. The metallographic analysis of the zinc layer should show the discontinuities and defects that contribute to the corrosion of the galvanized pipes. Furthermore, a critical view on this issue, with regard to the use of this material for natural gas and its behaviour in concrete and mortar environments, is taken.

\section{HOT-DIP ZINC GALVANIZING}

\subsection{Hot-dip zinc galvanization process}

The history of hot-dip zinc galvanization began in 1741, when the French chemist, P. Melouin, discovered that zinc was capable of protecting steel from corrosion. He presented his work to the French Royal Academy. However, an engineer, Stanislaw Sorel, is credited with the first patent for the immersion of carbon steel and iron in molten zinc (called galvanization), which was given on May 10, 1837 [5].

The hot-dip zinc galvanizing process essentially consists of immersing the iron or carbon steel pieces in a molten zinc bath at temperatures in the $440-470^{\circ} \mathrm{C}$ range to form a corrosion-resistant coating. The diffusion between the liquid zinc and iron during immersion forms a series of intermetallic layers that adhere to the carbon steel, which provides excellent barrier protection and cathodic protection when there are imperfections or eventual discontinuities on the coating [6-8].

However, the fabrication of a continuous, regular, uniform zinc layer of a certain thickness requires a fundamental sequence of procedures to be established that ensures the process meets the demands of various applications, such as complex structures, fastening elements and welded elements (e.g., wires, screws, pipes, beams, columns and plates). This sequence of procedures is shown in Figure 2. 


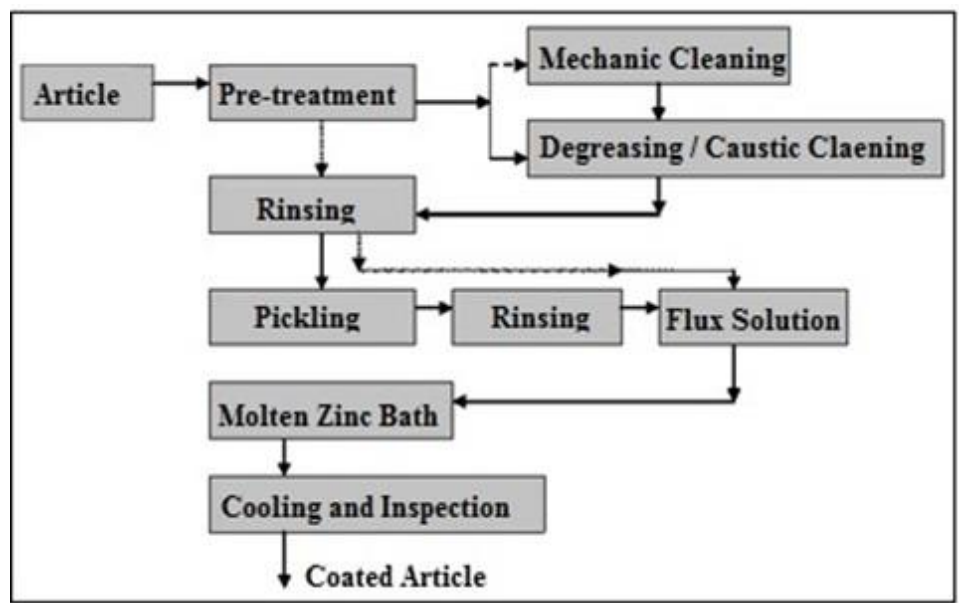

Figure 2: Hot-dip zinc galvanizing process.

Pre-treatment is performed to provide a chemically clean surface. Mechanical cleaning is conducted to remove any imperfections on the surface, using a range of options that include sandpaper, steel brushes, spatulas, hammers, rotary brushes and grinders. Chemical cleaning, in the form of degreasing, is implemented to remove any solid materials that may inhibit adherence to the surface, such as greases and oils.

The first rinsing ensures that there is no surface contamination during the pickling process, especially since acid pickling is used to remove any oxidation, incrustation or scales. Solutions based on hydrochloric and sulphuric acids are generally used, and the use of inhibitors is recommended to avoid sharp wear of metallic parts while also minimising hydrogen embrittlement. The used acid formulations range from 5 to $15 \%$ by volume and a bath temperature of 60 to $70^{\circ} \mathrm{C}$ is used for the sulphuric acid. The second rinsing removes any traces of the acid solution that may compromise the fluxing stage, as well as any metal salt residues that formed during the pickling process [6].

The acid-cleaned steel article is then dipped in a flux solution. This flux process serves two purposes: The zinc chloride and ammonium chloride portion of the solution is consumed to remove the remaining oxides on the metal surface and provide a clean surface to improve the diffusion and adhesion between the ferrous alloys and the molten zinc. The remainder of the solution exerts the wetting function (or mordent), which will provide efficient wetting of the article with the molten zinc.

The article is then immersed in the molten zinc bath. The immersion time determines the thickness of the zinc layer, which is generally 1 to $2 \mathrm{~min}$. Although the melting point of pure zinc is $419.5^{\circ} \mathrm{C}$, the bath is maintained at $440-470^{\circ} \mathrm{C}$ due to the operating conditions and the additions of the other metals that contribute to the improved adherence and diffusion of the zinc to the carbon steel $[6,7]$.

The formation and growth of the zinc layer is due to the interdiffusion of the zinc and iron atoms between the zinc-based and iron-based specimens immersed in the melting bath [9 $\mathrm{n}]$. The interdiffusion of these atoms in the molten bath generates a non-uniform layer, which is a function of the different chemical compositions, temperature and immersion time.

The metallurgical reaction that occurs between carbon steel and zinc is a unique feature of hot-dip zinc galvanizing barrier protection. Under normal conditions, the obtained coating is formed by intermetallic zinciron alloy layers $(\gamma, \delta$ and $\xi)$ and a layer of nearly pure zinc $(\eta ; 0.02 \% \mathrm{Fe})$, as shown in Figure 3.

Temperatures higher than the indicated the range lead to greater diffusion between the iron and zinc, which causes greater dissolution of the steel and a higher iron concentration in the final coating as a consequence. This higher iron concentration in the intermetallic layers generates a shorter and more fragile coating of the carbon steel. Higher temperatures also have a serious effect on the life of the vessel, as the reaction of the zinc with the walls of the vessel becomes more intense. The coated article is then cooled at the end of the operation, leaving it ready for any further operations. A layer of sacrificial or cathodic protection forms during the cooling process to protect the steel [6-8]. 


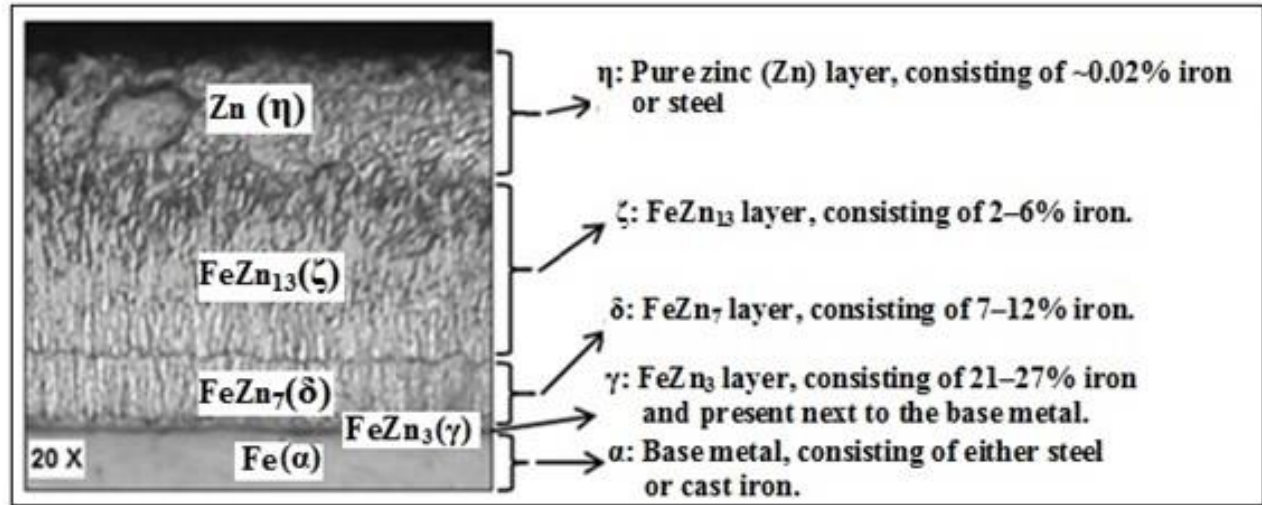

Figure 3: Micrograph of the alloy ( $\mathrm{Zn}-\mathrm{Fe})$ layers (20×magnification), with basic descriptions of their respective compositions.

The best performance of the final zinc layer may be conferred by the addition of certain metals to the bath. However, the presence of these metals and other contaminants in the molten zinc bath can generate undesirable metal inclusions and decrease the quality of the layers. These metals that are added to the bath, which alter the properties of the zinc coating, are nickel, aluminium, copper, lead, iron, cadmium and tin.

\subsection{Main specifications (standards) for the hot-dip zinc galvanizing process}

Brazilian and international standards that refer to hot-dip zinc galvanizing list a number of destructive and non-destructive processes and tests, such as terminology, relevant physical and mechanical characteristics, performance testing and industrial safety conditions. This includes, among others, the following three standards: ABNT (Brazilian Association of Technical Standards), ASTM (American Society for Testing and Materials) and DIN (Deutsches Institut für Normung). The basic specification for hot-dip zinc galvanized coating on iron and steel articles in Brazil was defined by Brazilian Standard ABNT NBR 6323 (Hot-dip Galvanized on Steel and Cast Iron Product) [1].

The thicknesses of hot-dip zinc galvanized coatings are generally in the 25-150 $\mu \mathrm{m}$ range, with most values falling into the $35-120 \mu \mathrm{m}$ range. The majority of the standards relate the zinc mass per coated area ( $\mathrm{g}$ of zinc $\left./ \mathrm{m}^{2}\right)$ to the thickness $(\mu \mathrm{m})$. Therefore, $1 \mathrm{~g}$ of zinc $/ \mathrm{m}^{2}$ corresponds to a thickness of 0.139 to $0.143 \mu \mathrm{m}$. The key specifications for carbon steel galvanized pipes based on ABNT Brazilian Standards are listed in Table $1[1]$.

Table 1: Specifications of the carbon steel galvanized pipes ABNT 6323 [1].

\begin{tabular}{|l|c|c|}
\hline \multicolumn{1}{|c|}{ Galvanized Materials } & $\begin{array}{c}\text { Minimum Coating } \\
\text { Mass }\left(\mathrm{g} / \mathrm{m}^{2}\right)\end{array}$ & $\begin{array}{c}\text { Minimum Coating } \\
\text { Thickness }(\mu \mathrm{m})\end{array}$ \\
\hline Thickness $\leq 2.0 \mathrm{~mm}$ & 300 & 42 \\
\hline $2.0 \mathrm{~mm} \leq$ Thickness $\leq 4.0 \mathrm{~mm}$ & 350 & 49 \\
\hline
\end{tabular}

The thickness can be determined by thickness gauges that are based on the magnetic flux variation outlined in Brazilian Standard ABNT NBR 7399 [10]. The presence of zinc coating that possesses different magnetic properties than those the steel provides a variation in the measurement of the magnetic flux and, with the standardisation determined by the resultant thickness patterns.

Figure 4 illustrates the adherence of the zinc layer to carbon steel in two moments, highlighting that a certain degree of variability may exist for a given mass of zinc $/ \mathrm{m}^{2}$ on the surface. It therefore follows that the zinc coating can meet the standard for the mass of zinc $/ \mathrm{m}^{2}$, but it may not meet the specification for a uniform zinc layer and thus become subject to more localised corrosion as a consequence. 


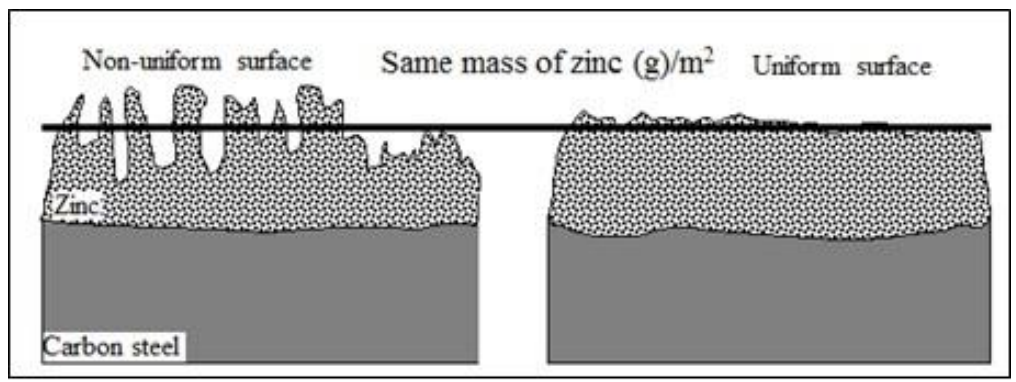

Figure 4: Visualisation of a non-uniform (left) and uniform (right) zinc layer on carbon steel.

Finally, the zinc coating must be continuous, uniform, adherent and free from defects, including oxidation, peeling or detachment, run-off, porosity, bubbles, ripples, lumps, roughness and bare points (Figure 5), which may compromise the performance and durability of this coating under normal use. The preliminary inspection must therefore verify the articles, identify the tubes and fittings with defects, and then correct these defects, when possible.

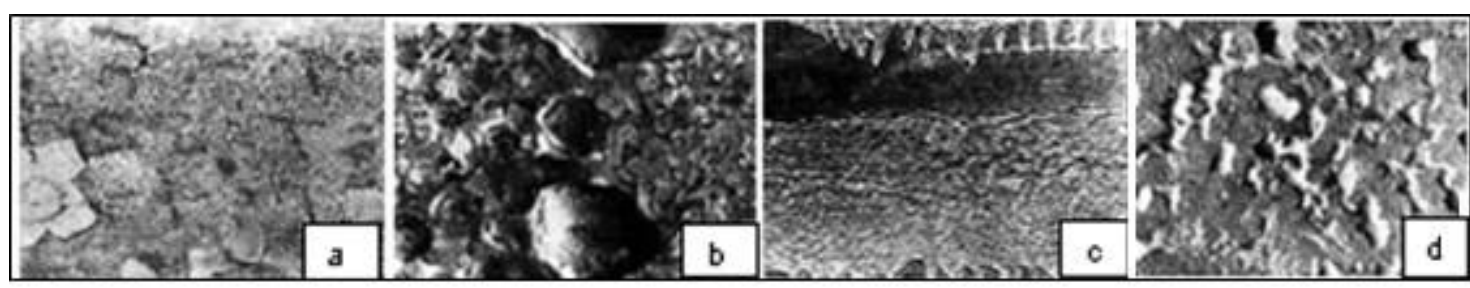

Figure 5: Zinc coating defects: a) Peeling. b) Bubbles. c) Runs. d) Oxidation.

\section{MATERIALS AND METHODS}

The performance of the zinc coating of galvanized pipes for natural gas was evaluated by collecting pipes removed from floors (Figure 1) and new tubes that had not been used. The tubes were cut and identified in the following valuations.

\subsection{Determination of the mass of zinc per square meter of surface area $\left(\mathrm{g} / \mathrm{m}^{2}\right)$}

The determination of the applied grams of zinc per square meter of surface area $\left(\mathrm{g} / \mathrm{m}^{2}\right)$ is an important parameter in the qualification of zinc-plated materials, and is outlined in Brazilian Standards ABNT NBR 7397 [2] and ASTM A90 [11]. The test consists of two steps, where the coated area of zinc is measured, the specimen is cleaned with organic solvents, and the zinc-coated specimen is then weighed in the first step. In a second step, the specimens are immersed in a hydrochloric acid solution containing a corrosion inhibitor to protect the base metal (steel or iron). The specimens are washed in running water and the alcohol after pickling, and they are subsequently dried with hot air to be weighed without the zinc coating. The results of the tests are determined by equation (1), which identifies the mass difference of the zinc mass ( $\mathbf{m}_{\mathbf{z i n c}}$ ) present in the coating:

$$
\mathbf{m}_{\text {zinc }}=\left(\mathbf{w}_{1}-\mathbf{w}_{2} / \mathbf{A}\right)
$$

where $A$ is the total area of the test piece $\left(\mathrm{m}^{2}\right), w_{1}$ is the initial mass of the coated specimen $(\mathrm{g})$ and $w_{2}$ is the final mass of the uncoated test specimen $(\mathrm{g})$. Ten samples were used in this test.

\subsection{Determination of the uniformity of the zinc layer}

Since the thicknesses of the zinc coating are determined by the average of the mass of zinc applied per unit area, it is fundamental that there is uniformity in the deposited zinc coating to decrease the potential for failures and guarantee a product with greater durability. The Preece test is an effective method for evaluating the uniformity of zinc deposits, as certified by ABNT NBR 7400 [12] in Brazil. The test basically consists of immersing the zinc-coated sample in standard solution of cupric sulphate $\left(\mathrm{CuSO}_{4}\right)$. The electrochemical attack is controlled by the one-minute immersion time. This norm indicates a total of six immersions for each test. The test is completed when a brilliant and adherent copper deposit appears on the surface of the steel based on the following chemical reaction: $\mathrm{Fe}+\mathrm{CuSO}_{4} \rightarrow \mathrm{Cu}+\mathrm{FeSO}_{4}$. The zinc layer is deemed uniform when a 
brilliant and adherent copper deposit does not appear on the steel surface during the six immersions. In this valuation were used ten sample tubes.

\subsection{Metallographic analysis of the deposited zinc layer}

Metallographic analysis of the galvanized pipes aims to evaluate the aspects of the deposition, with an emphasis on the uniformity of the zinc layer. The samples consisted of 2-cm-long pipe cross sections. The surface was prepared using a grinding machine, followed by sanding using a rotational machine with different-sized silicon carbide papers (80-1200 mesh). The samples were washed with water and ethyl alcohol during each stage of the sanding process. Successive polishing steps were then performed using a paste of $1.0 \mu \mathrm{m}$ alumina $\left(\mathrm{Al}_{2} \mathrm{O}_{3}\right)$. The microstructures were revealed using a $2 \%$ Nital solution (metallographic solution consisting of $2 \mathrm{~mL}$ of $\mathrm{HNO}_{3}$ to $65 \%$ and $98 \mathrm{~mL}$ of hydrated alcohol) that were observed with an optical microscope [13, 14].

\subsection{Experimental evaluation of the natural gas pipe in building constructions}

An experiment was developed to reproduce the same conditions of subfloors (mortar beds) where galvanized pipes have been installed (Figure 1), and therefore explain the corrosion process that is occurring in natural gas pipes in various building facilities. This test was developed by the authors and is currently not included in the Brazilian standards.

A $50 \mathrm{~cm} \times 50 \mathrm{~cm} \times 10 \mathrm{~cm}$ wooden box (Figure 6) was built to conduct this experiment. Galvanized pipes were placed inside the box, with a variable cover thickness $(10,30$ and $50 \mathrm{~mm})$, and a mortar consisting of a 1:3 cement: sand mixture and little water were then added, as shown in Figure 7. The Portland cement used in this test is the common type (CP1) according to the Brazilian Standard ABNT NBR 11578:1997 [15]. The sand used is dry and free of chloride $\left(\mathrm{Cl}^{-}\right)$, while the added water follows the standards of drinking.

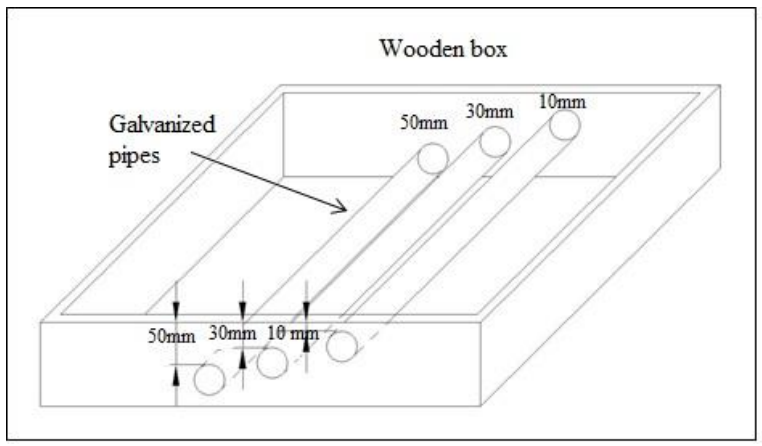

Figure 6: Wooden box with galvanized pipes.

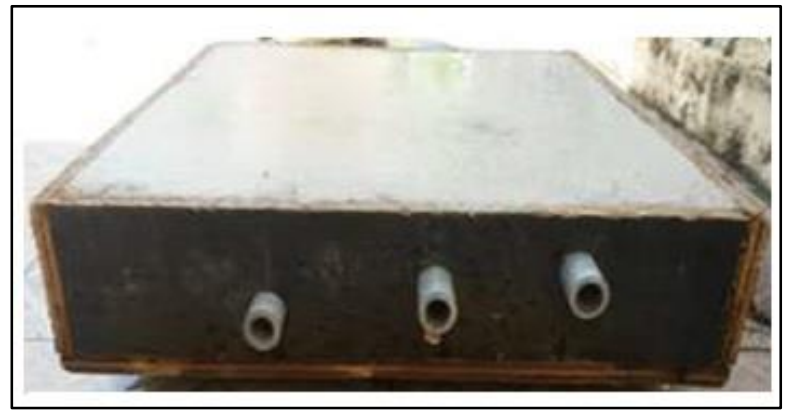

Figure 7: Wooden box, galvanized pipes and mortar, consisting of a 1:3 cement: sand mixture and little water.

The curing time of the concrete was 14 days [16], with the various tests conducted after the concrete was dry. A spray of $200 \mathrm{~mL}$ municipal water was applied four days a week on the surface of the concrete body during the exposure time, while other bodies were totally dry. The exposure times of each experiment were fixed at 40, 90 and 180 days. After the tests were completed, the galvanized pipes were exposed by cutting the concrete into $5 \mathrm{~cm} \times 5 \mathrm{~cm}$ squares with a manual saw and then removing it with a chisel (Figure 8), where the galvanized pipes could then be inspected to identify the degree and extent of corrosion. 


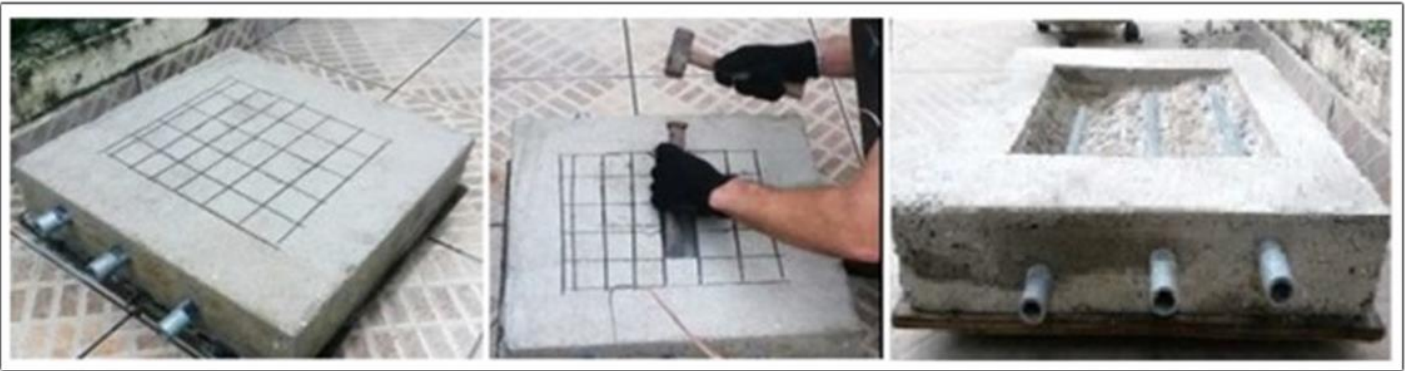

Figure 8: Cutting into the concrete body to evaluate the galvanized tubes.

It is important to note that the cover thicknesses of concrete used in the tests was based on the parameters, guidelines and procedures outlined in civil construction. The general recommendations depend on the aggressiveness (weak, moderate, strong and very strong) of the corrosive medium. The cover thicknesses of concrete can therefore vary from 25 to $55 \mathrm{~mm}$, as shown in Figure 9 [17].

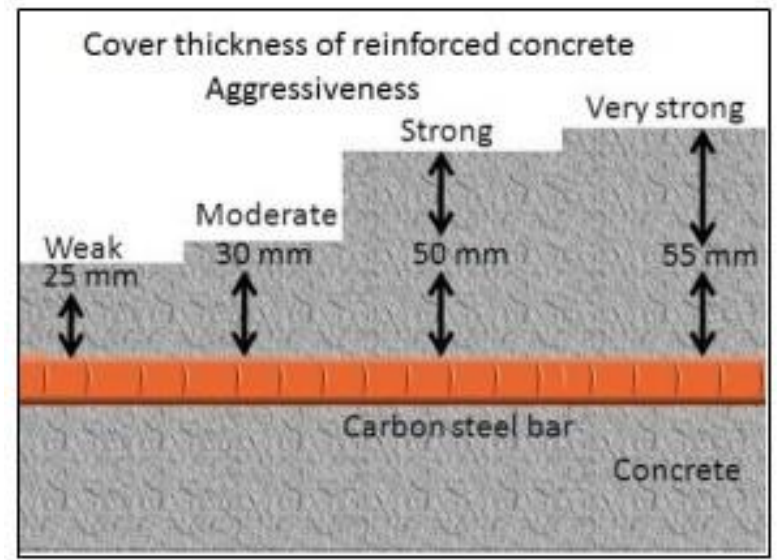

Figure 9: Cover thickness of reinforced concrete [17].

\section{RESULTS AND DISCUSSION}

\subsection{Determination of the mass of zinc/area and uniformity test}

The results were then compared to the analyses conducted on the new (unused) galvanized pipes. The ten samples presented an average mass per unit area of $530 \mathrm{~g}$ of $\mathrm{zinc} / \mathrm{m}^{2}$, which is well above the $350 \mathrm{~g}$ of $\mathrm{zinc} / \mathrm{m}^{2}$ (Table 1) established by Brazilian Standard ABNT NBR 6323 [1]. These masses correspond to average thicknesses of 76.6 and $49.0 \mu \mathrm{m}$, respectively.

A non-uniform zinc layer was present in $60 \%$ of the samples from the new pipe (unused) and Preece Test evaluations (coating uniformity) [12]. However, it is important to note that the masses of zinc deposited on the surfaces of the carbon steel tubes have always been performed in accordance with the Brazilian Standards [1]. Figure 4 exemplifies and reinforces the premise that although the mass of zinc deposited can be approved in the Brazilian and international standards specifications, the non-uniformity (irregularly) of the zinc layer will certainly promote and accelerate carbon steel tube corrosion.

The non-uniformity of the zinc layer deposited on the carbon steel pipe can be due of various control parameters in molten zinc bath that occur during processing, which include the immersion time, the temperature, inadequate cleaning of the surface [6-8] and the inclination of tube for the draining of the liquid zinc during the removal of the tube from molten zinc bath (Figure 10). 


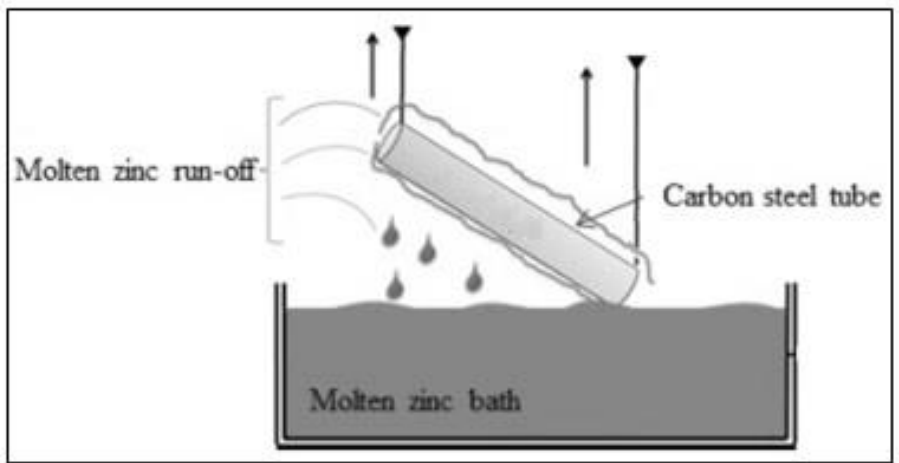

Figure 10: Hot-dip zinc galvanizing process.

\subsection{Metallographic evaluation of the zinc layer}

Although the galvanized pipes are being used in the context of natural gas in building construction, only the external surface of the tubes was evaluated to determine the effectiveness of the zinc coating. The inside of the tube was not evaluated, because residential/commercial natural gas is adequately treated and considered inert within the limits. However, raw natural gas may contain $\mathrm{CO}_{2}, \mathrm{H}_{2} \mathrm{~S}$ and humidity $\left(\mathrm{H}_{2} \mathrm{O}\right)$, all of which are fairly aggressive agents to zinc coatings $[18,19]$.

As mentioned above, the zinc layer formation on the carbon steel surface is the result of the diffusion of carbon steel $(\mathrm{Fe})$ with liquid zinc in the $440-470^{\circ} \mathrm{C}$ range, forming three intermediate zinc-iron alloy layers $(\gamma$, $\delta$ and $\zeta$ phases $)$ and a layer of nearly pure zinc $(0.02 \%$ Fe; $\eta$ phase $)$. The microstructures, Fe-Zn composition, the extension of the zinc layer and uniformity are functions of various parameters, including temperature, immersion time, preparation of the surface of the tubes, carbon steel composition and impurities in liquid zinc bath) $[6-8,20]$.

The micrograph in Figure 11 shows a sample taken from an unused tube, with a thickness of $>50 \mu \mathrm{m}$ that is uniform according to the Preece test. It shows the solid structure with the various phases resulting from the diffusion of carbon steel with molten zinc. The three Fe-Zn phases are well defined, with each possessing an appropriate and regular thickness without much variation, although micro fissures are present. Such micro fissures in the regions can possibly provide poor adherence to the carbon steel.

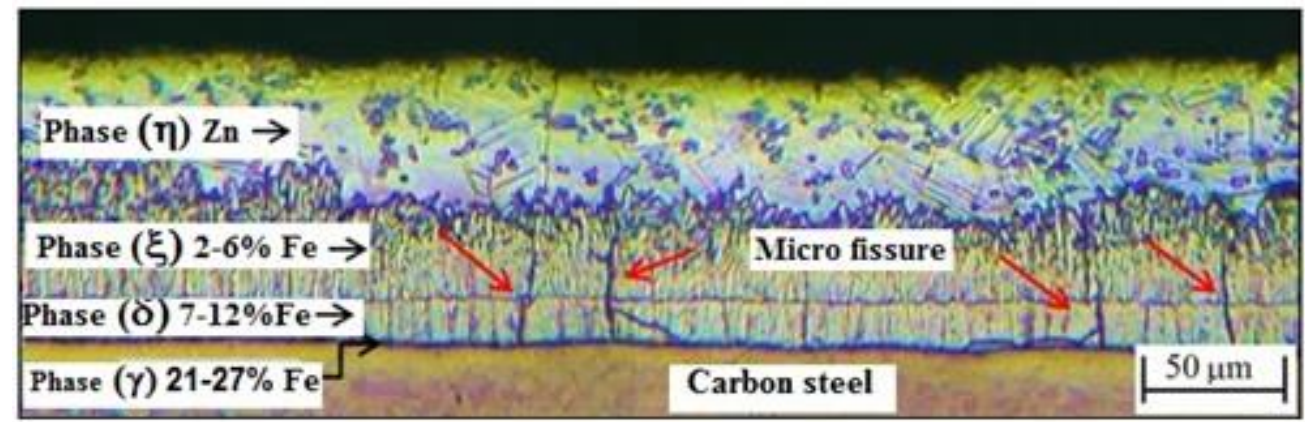

Figure 11: Micrograph of the zinc layer on carbon steel showing the $\gamma, \delta, \zeta$ and $\eta$ phases.

The micrographs shown in Figures 12 to 17 are from unused tubes that did not obtain good results in the uniformity tests (Preece test). Figures 12 and 13 show a disproportionate growth of the $\zeta$ phase (consisting of $2-6 \%$ iron) layer compared to irregular and thin $\eta$ phase (pure zinc) layer. The micrographs in Figures 14 and 15 show a layer of zinc exceeding $50 \mu \mathrm{m}$, with cracks and the occasional absence of the zinc layer, confirming that non-uniformity can provide localised corrosion points. The micrograph presented in Figures 16 were from the tubes removed from the floor, as shown in Figure 1, where clear discontinuities and the occasional absence of the zinc layer on the surface of the carbon steel are observed. 


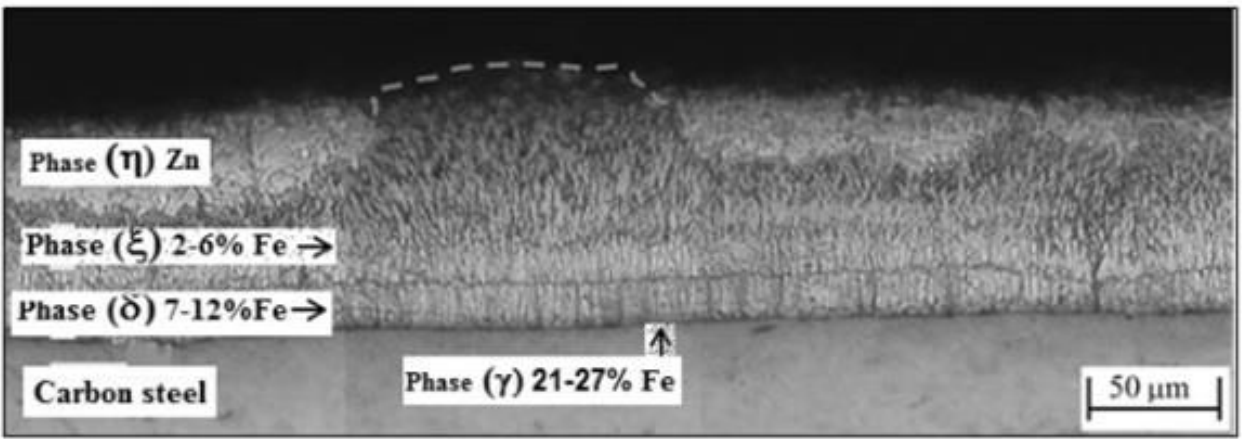

Figure 12: Micrograph highlighting the disproportionate growth of the $\zeta$ phase in comparison to the $\eta$ phase

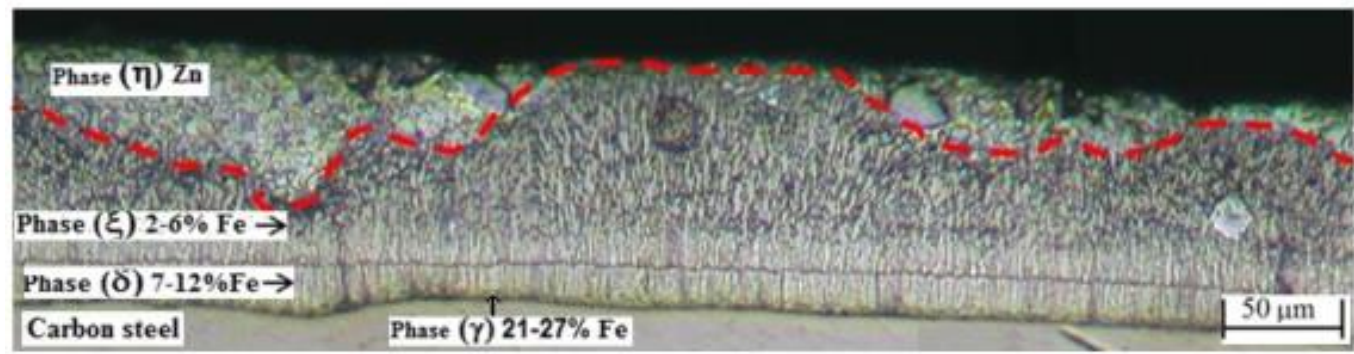

Figure 13: Micrograph highlighting the disproportionate growth of the $\zeta$ phase in comparison to the $\eta$ phase.

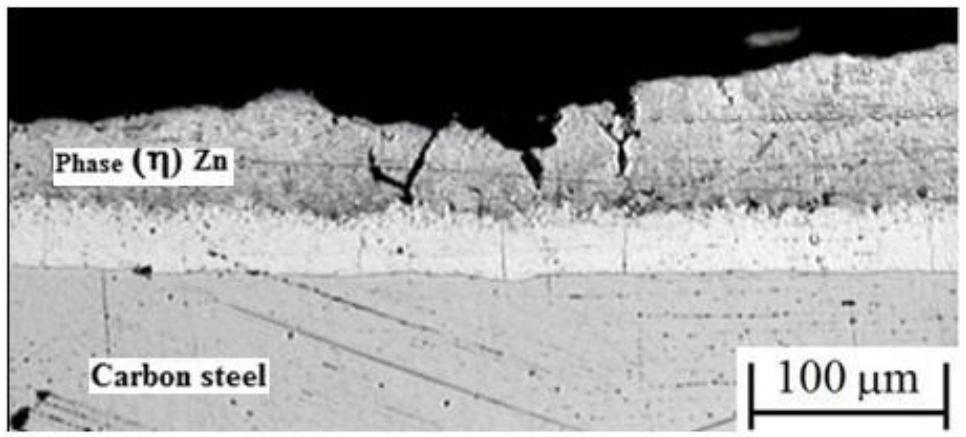

Figure 14: Micrograph of a zinc layer exceeding $50 \mu \mathrm{m}$, with cracks.

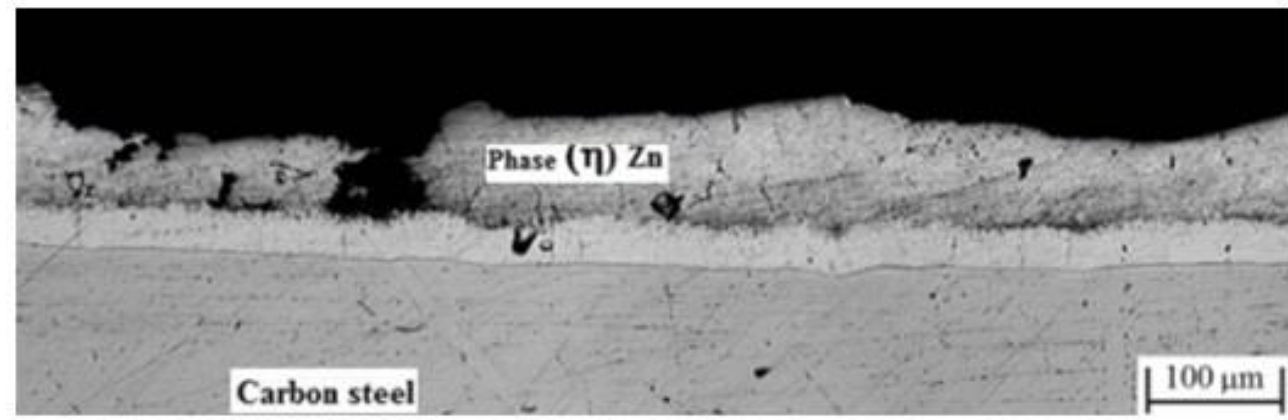

Figure 15: Micrograph of a zinc layer exceeding $50 \mu \mathrm{m}$, with the occasional absence of the pure zinc layer. 


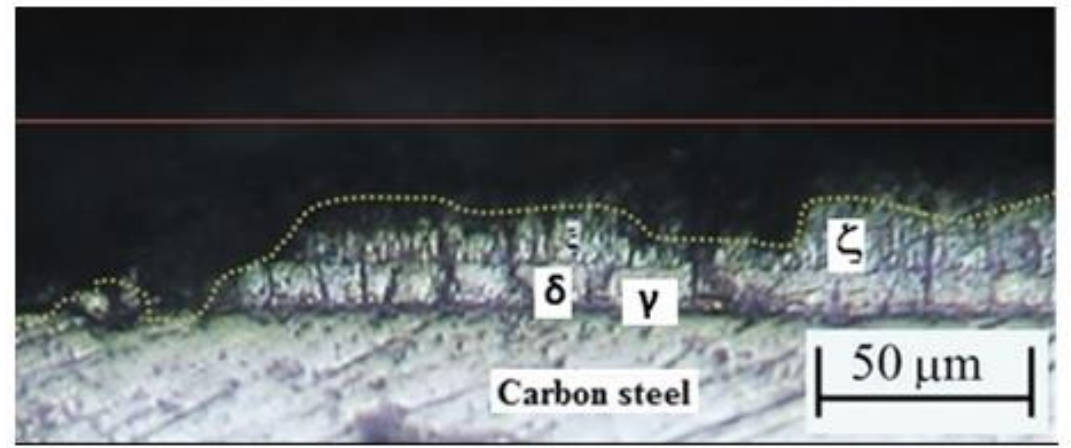

Figure 16: Micrograph showing the discontinuity and absence of a zinc layer on a carbon steel surface.

\subsection{Results of experiment for evaluation of natural gas pipe in building constructions}

The galvanized tubes were removed from the dry environment experiment shown in Figure 17, where there was no wetting with municipal water sprinkling. They were completely dry and no localised corrosion points were observed, with only a tenuous common and protective zinc hydroxide formation. Furthermore, no localised corrosion was observed on the tubes with discontinuities.

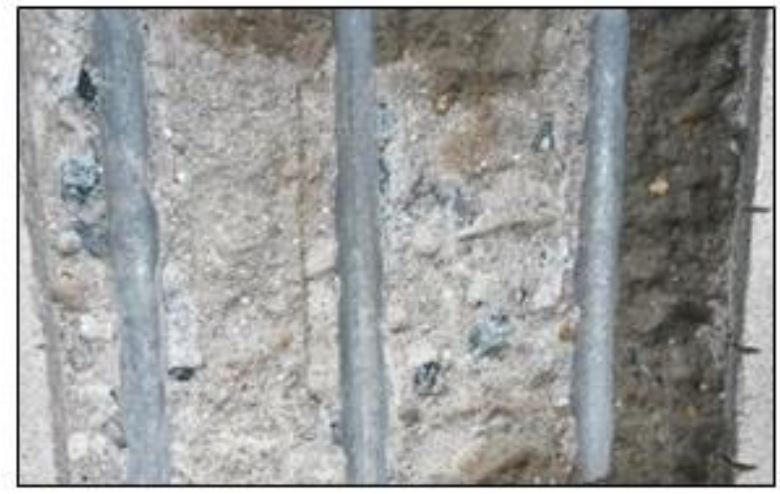

Figure 17: Galvanized tubes in the dry environment experiment (without water spray).

The experiments with water spray showed that some galvanized tubes (Figure 18) presented localised corrosion points, primarily consisting of discontinuities similar to those shown in the previous micrographs.

There is no doubt that the tubes at lower depths in the concrete floor and in the highest water absorption areas promote corrosion in the galvanized tubes. Furthermore, tubes with irregularities or discontinuities in the zinc coating are subject to more localised corrosion.

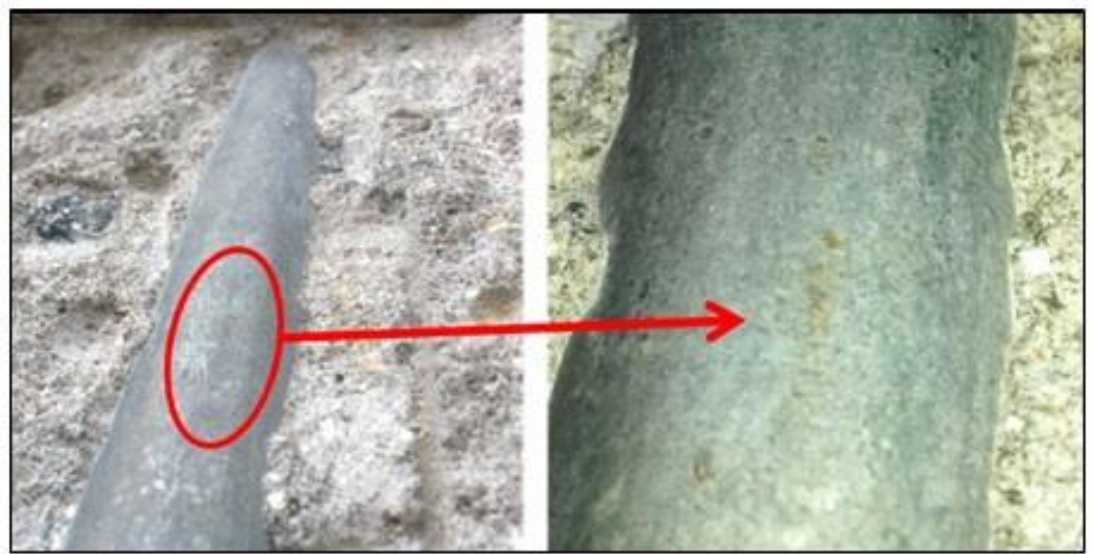

Figure 18: Localized corrosion points. 


\section{CONCLUSIONS}

The following conclusions are made based on the tests performed here:

- It is important to clarify that the zinc coating by the hot-dip zinc galvanized process is an interdiffusion between the zinc and carbon steel, forming several intermetallic phases $(\gamma, \delta, \zeta)$, with the last one $(\eta)$ consisting of practically pure zinc.

- The zinc barrier formed on the surface of the carbon steel is not monolithic, as is the case for the electrodeposition process of zinc in carbon steel.

- The great advantages of the hot-dip zinc galvanized process are its simplicity, the large zinc thickness and its low cost.

- It is important to state that the mass of $\mathrm{zinc} / \mathrm{m}^{2}$ can be above of the values set in the standards. However, this does not mean that there are no discontinuities or irregularities in the zinc coating applied to the carbon steel surface.

- The tests conducted with galvanized tubes that represented a concrete floor did not show any localised corrosion in dry environments (without water spray), even in the tubes with discontinuities. However, the probability of localised corrosion increased in wet environments (with water spray), particularly in the tubes with discontinuities in their zinc coatings.

- It is common for natural gas pipes pass under the hallways of residential buildings and/or offices, often within 1 to $2 \mathrm{~cm}$ of the floor. It is therefore essential to have warnings that indicate the passage of such pipes for safety purposes. Kitchens and service areas that are subject to the permeation of water and cleaning products must have good waterproofing to ensure the galvanized tubes and natural gas conductors are not compromised.

\section{BIBLIOGRAPHY}

[1] ASSOCIAÇÃO BRASILEIRA DE NORMAS TÉCNICAS. ABNT NBR 6323, Galvanização por imersão a quente de produtos de aço e ferro fundido - Especificação (Hot-dip galvanizing on steel and cast iron products-Specification), Rio de Janeiro, Brazil: ABNT, 2016, (Brazilian Standards in Portuguese).

[2] ASSOCIAÇÃO BRASILEIRA DE NORMAS TÉCNICAS. ABNT NBR 7397, Galvanização por imersão a quente de produtos de aço e ferro fundido; Determinação da massa do revestimento por unidade de área (Hot-dip galvanizing on steel and cast iron products-specification; determination of coating mass per unit area), Rio de Janeiro, Brazil: ABNT, 2016, (Brazilian Standards in Portuguese).

[3] ASSOCIAÇÃO BRASILEIRA DE NORMAS TÉCNICAS. ABNT NBR 15526, Redes de distribuição interna para gases combustíveis em instalações residenciais; Projeto e execução (Internal distribution for combustible gases in residential facilities; design and implementation). Rio de Janeiro, Brazil: ABNT, 2016, (Brazilian Standards in Portuguese).

[4] MAINIER, F. B. "A qualidade das tubulações zincadas utilizadas na construção civil (The quality of zinc tubes used in civil construction)", Engevista, v.5, n.10, pp.85-93, 2003, (in Portuguese).

[5] ROBERGE, P. R. Handbook of corrosion engineering, McGraw-Hill, 2000.

[6] HANDBOOK, A. S. M. "Hot Dip Coatings", In: Corrosion, vol. 13. ASM International, pp.740-754, 1987.

[7] MARDER, R. A., "The metallurgy of zinc-coated steel", Progress Materials Science., v.45, pp.191-271, 2000.

[8] SHIBLI, S. M. A., MEENA, B. N., REMYA, R., "A review on recent approaches in the field of hot dip zinc galvanizing process", Surface and Coating Technology, v.262, pp.210-215, 2015.

[9] DI COCCO, V., IACOVIELLO, F., NATALI, S., "Damaging micromechanisms in hot-dip galvanizing Zn based coatings", Theoretical and Applied Fracture Mechanics, v.70, pp.91-98, 2014.

[10] ASSOCIAÇÃO BRASILEIRA DE NORMAS TÉCNICAS. ABNT NBR 7399, Produto de aço e ferro fundido galvanizado por imersão a quente -Verificação da espessura do revestimento por processo não destrutivo (Hot-dip galvanizing on steel and cast iron products-specification; Verification of coating thickness by non-destructive process), Rio de Janeiro, Brazil: ABNT, 2016, (Brazilian Standards in Portuguese).

[11] AMERICAN SOCIETY FOR TESTING AND MATERIALS INTERNATIONAL. ASTM A90/A90M13, Standard test method for weight [mass] of coating on iron and steel articles with zinc or zinc-alloy coatings, Pennsylvania, USA: ASTM International, 2013.

[12] ASSOCIAÇÃO BRASILEIRA DE NORMAS TÉCNICAS. ABNT NBR 7400, Produto de aço e ferro 
fundido galvanizado por imersão a quente - Verificação da uniformidade do revestimento (Hot dip galvanizing on steel and cast iron products dipping; checking coating uniformity), Rio de Janeiro, Brazil: ABNT, 2016, (Brazilian Standards in Portuguese).

[13] PISTOFIDIS, N., VOURLIAS, G., KONIDARIS, S., et al., "Microstructure of zinc hot-dip galvanized coatings used for corrosion protection”. Materials Letters, v.60, n.6, pp.786-789, 2006.

[14] COLPAERT, H. Metalografia dos produtos siderúrgicos comuns (Metallography of common steel products). $3^{\mathrm{a}}$. ed. São Paulo, Edgard Blucher, 1974,( in Portuguese).

[15] ASSOCIAÇÃO BRASILEIRA DE NORMAS TÉCNICAS. ABNT NBR 11578:1997, Cimento Portland composto - Especificação (Portland composite cement - Specification), Rio de Janeiro, Brazil: ABNT, 1997 , (Brazilian Standards in Portuguese).

[16] NEVILle, A. A., BROOKS, J. J., Concrete Technology, second ed., Pearson Education Ltd., Essex, 2010.

[17] MAINIER, F. B., ALMEIDA, P. C. F., NANI, B. F., et al., "Corrosion caused by sulfur dioxide in reinforced concrete", Open Journal of Civil Engineering, v.5, n.4, pp.379-389, 2015.

[18] KERMANI, M. B., MORSHED, A. "Carbon dioxide corrosion in oil and gas production - a compendium”, Corrosion, v.59, n.8, pp.659-683, 2003.

[19] CARROLL, J., Natural gas hydrates: a guide for engineers, third ed., Gulf Professional Publishing, Waltham, 2014.

[20] CULCASI, J. D., SERE, P. R., ELSNER, C. I., et al., "Control of the growth of zinc-iron phases in the hot-dip galvanizing process", Surface and Coating Technology, v.122, n.1, pp. 21-23, 1999.

\section{ORCID}

Fernando B. Mainier

https://orcid.org/0000-0002-8203-5543

Humberto Nogueira Farneze

https://orcid.org/0000-0001-9615-1468

Rodolfo Shamá

https://orcid.org/0000-0001-7603-7764 